\title{
Ascorbic acid biosynthesis: a precursor study on plants
}

\author{
Anderson D. Barata-Soares', Maria Luiza P. A. Gomez ${ }^{*}$, Carlos Henrique de Mesquita ${ }^{2}$ and Franco M. \\ Lajolo $^{1}$
}

${ }^{1}$ Departamento de Alimentos e Nutrição Experimental, Faculdade de Ciências Farmacêuticas, Universidade de São Paulo, Av. Lineu Prestes 580, Bloco 14, CEP 05508-970, São Paulo, SP, Brasil; ${ }^{2}$ Instituto de Pesquisas Energéticas e Nucleares, Av. Professor Lineu Prestes 2242, Cidade Universitária, CEP 05508-000, São Paulo, SP, Brasil.*Corresponding author: malusp@usp.br Received:02/07/2004, Accepted: 25/11/2004

Since the first isolation of ascorbic acid (AsA) in 1928, few papers have been published regarding the biosynthesis of AsA in plants, especially in fruits. It took as long as 1998, before Wheeler, Jones and Smirnoff, based on a study with Arabidopsis leaves, proposed what can be considered the main pathway of biosynthesis of AsA, in which L-galactose (L-GAL) is a key precursor. This paper reports the effectiveness of some precursors (cold or radiolabeled) in the biosynthesis of AsA in different plants: green sweet pepper, white-pulp guava, red-pulp guava, papaya and strawberry at two ripening stages (mature green and ripe for papaya and mature green and half red for strawberry) and broccoli. The 'Smirnoff-Wheeler' pathway was functioning and active in all sources studied, as demonstrated by the increase in AsA contents and incorporation of labeled precursors into AsA. In papaya, the AsA content in the ripe fruit was higher than in the mature green, indicating the synthesis of AsA during ripening. On the other hand, the AsA content in the mature green strawberry was similar to that of the half red fruits. Our data demonstrate that L-GAL and L-Galactono-1,4-lactone (L-GL) are effective precursors for the biosynthesis of AsA in fruits and also provided additional evidence for the participation of D-mannose (D-MAN) and D-glucose-1P in the biosynthesis of AsA in plants.

Key words: ascorbate, ascorbate biosynthesis pathway, antioxidant, precursor infiltration.

Biossíntese de ácido ascórbico - um estudo com precursores em plantas: Apesar da importância do ácido ascórbico (AA) para os organismos animais e vegetal, sua biossíntese somente foi elucidada em 1998, quando Wheeler, Jones e Smirnoff demonstraram, em folhas de Arabidopsis, que L-galactose (L-GAL) é um precursor chave. Neste trabalho, investigou-se a atuação de supostos precursores na síntese do AA em diferentes fontes vegetais: pimentão-verde, goiabas de polpa branca e vermelha, mamão e morango em dois estádios do amadurecimento: verde e maduro para o mamão e verde e rosa para o morango e em brócolis, verificando-se a atuação da via "Smirnoff-Wheeler" mediante a constatação do aumento dos conteúdos de AA e incorporação de precursores radiativamente marcados. O conteúdo de AA no mamão maduro apresentou-se maior do que no verde, indicando que há predomínio da síntese durante o amadurecimento desse fruto. $\mathrm{O}$ mesmo não ocorreu com o morango, onde não houve diferenças significativas entre os conteúdos de AA nos frutos verde e intermediário. Os resultados confirmaram que a L-GAL e a L-galactono-1,4-lactona (L-GL) são precursores bastante eficientes do AA, e também que há síntese de AA a partir de D-manose (D-MAN), L-GAL e D-glicose-1P nos vegetais estudados.

Palavras-chave: antioxidantes, ascorbato, biossíntese do ascorbato, infiltração de precursores.

\section{INTRODUCTION}

Ascorbic acid (AsA) plays important roles in the human organism, such as conjunctive tissue formation, ion transportation, and cell protection against free radicals. In plants, it also plays a protective role against reactive oxygen species that are formed from photosynthetic and respiratory processes. AsA is linked to cell growth, being involved in the cell cycle and other mechanisms of plant cell growth and division, as well as acting as a co-factor for many enzymes (Smirnoff, 1996; Lee and Kader, 2000). 
Despite the importance of AsA, its biosynthetic pathway in different plant parts is not completely understood. In 1998, Wheeler and colleagues proposed the first pathway to gain acceptance. Before this, many other pathways and mechanisms were studied, but no consensus was reached (Loewus et al., 1956; Isherwood and Mapson, 1962).

The so-called "Smirnoff-Wheeler" pathway for AsA biosynthesis has as its immediate precursor L-galactono-1,4lactone (L-GL), and the intermediates involved are phosphorylated sugars and nucleotide-linked sugars (figure 1). Several studies have confirmed this mechanism, and some of the enzymes involved have been detected and described (Oba et al., 1995, Gatzek et al., 2002). This pathway would appear to be the main one for the biosynthesis of AsA, but other pathways cannot be discarded. One example is the conversion of D-galacturonic acid (D-GalUA) into L-GL, first shown by Loewus and Kelly (1961) and confirmed by Davey et al. (1999). D-GalUA and, to a lesser extent, L-Gal are constituents of the cell wall, which may be the source of this secondary pathway for the biosynthesis of AsA in plants (Smirnoff et al., 2004). Recently, a specific D-GalUA reductase was cloned and overexpressed in strawberry, leading to higher contents of AsA (Agius et al., 2003). Other pathways, in which AsA is derived from gulonic acid, gluconic acid and araboascorbate, and glucosone and sorbosone (Loewus et al., 1990, Saito et al., 1990, Saito, 1996) may occur, but they appear to be of lesser importance (Smirnoff et al., 2004).

Genetic evidence for AsA biosynthesis has been obtained with the help of an Arabidopsis thaliana mutant, which shows AsA levels about $30 \%$ lower than the wild type. This deficiency is due to a lower activity of GDP-D-mannose-3,5epimerase, which catalyzes the conversion of D-mannose-1phosphate to GDP-D-mannose (Conklin et al., 1999). This enzyme also participates in other processes, such as cell wall carbohydrate biosynthesis and protein glycosylation in eukaryotic cells and the product GDP-Man is a source of mannose for the cell wall (Smirnoff and Wheeler, 2000; Smirnoff et al., 2004).

The infiltration of AsA precursors has been used to study and establish pathways of biosynthesis and degradation in plants. Infiltration of D-[6- $\left.{ }^{14} \mathrm{C}\right]$-glucose and D-[6- $\left.{ }^{14} \mathrm{C}\right]-$ glucosone in bean seedlings led to a $0.4 \%$ conversion into AsA (Loewus et al., 1987). Furthermore, D-[1- $\left.{ }^{14} \mathrm{C}\right]$-glucose infiltration in watercress, parsley and geranium leaves has confirmed the conversion of D-glucose into AsA (Loewus and Jang, 1957; Williams and Loewus, 1978; Helsper et al., 1982). In geranium leaves, Loewus et al. (1975) reported that
D-[1- $\left.{ }^{14} \mathrm{C}\right]$-glucose infiltration formed about 9-fold more radiolabeled oxalic acid (AOx, an AsA degradation product) than $\mathrm{D}-\left[6-{ }^{14} \mathrm{C}\right]$-glucose infiltration, which formed $82 \%$ of the AsA marked with the radioactive carbon in the position 6 . The synthesis of AOx from AsA has been an object of several studies (Keates et al., 2000; Kostman et al., 2001; DeBolt et al., 2004) where it was demonstrated by radiolabel infiltration and detection of labeled AOx and other AsA cleavage products, such as tartaric acid (TA). In Vitis vinifera, DeBolt et al. (2004) demonstrated that AsA cleavage may occur in different plant organelles, originating both AOx and TA. This seems to be a directed process, which may be important for the formation of calcium oxalate and calcium tartrate crystals for the control of calcium concentration in the cells, as well as remobilization of calcium at specific stages of fruit development. In fact, the formation of AOx, TA and other

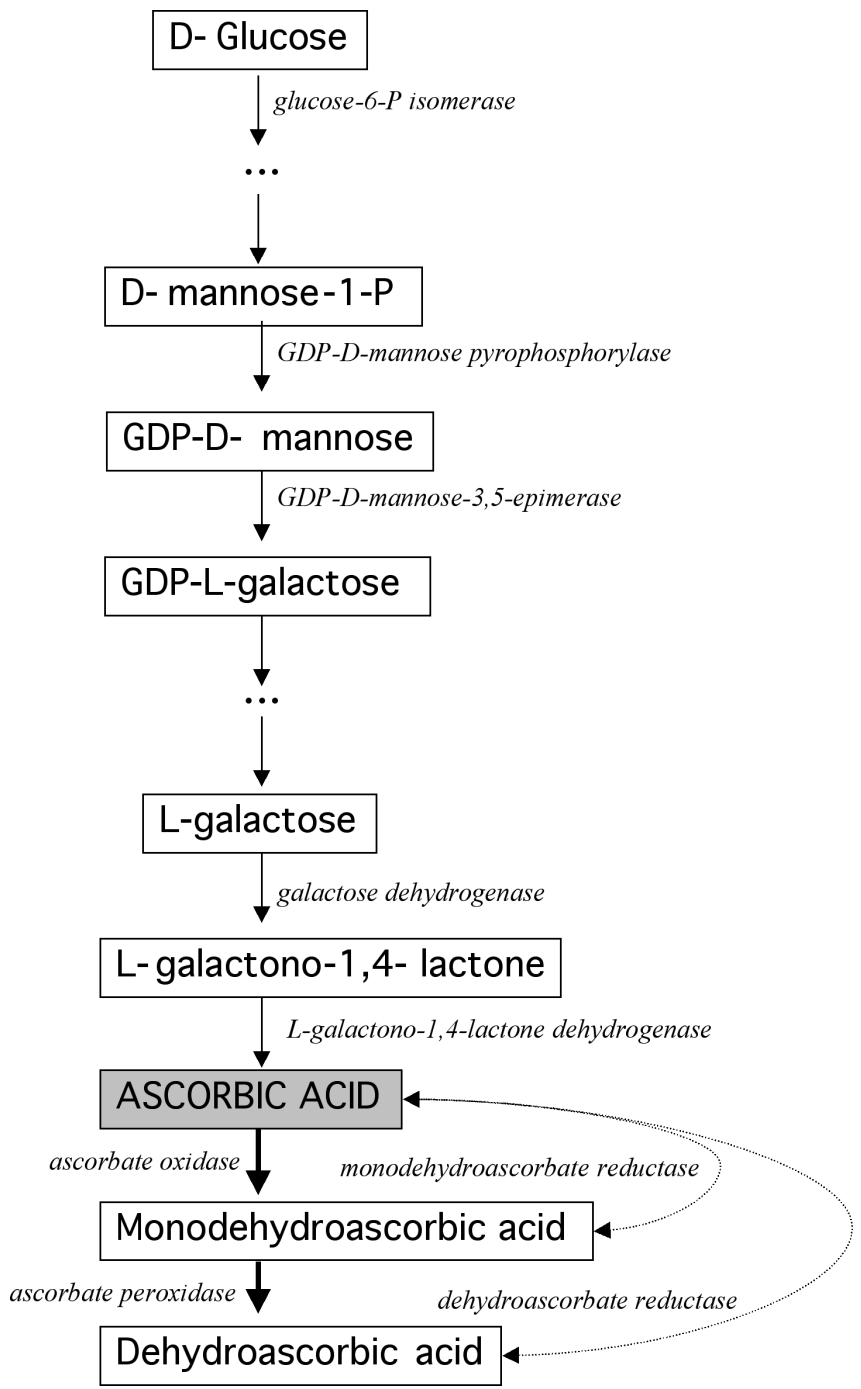

Figure 1. Pathway of ascorbic acid biosynthesis and biodegradation. 
organic acids is a result of AsA metabolism in grape berries and other plants (Wagner and Loewus, 1974; Saito and Loewus, 1989; DeBolt et al., 2004), and may contribute to the balance of AsA content in plants.

The conversion of L-GL into AsA is consensual, and has been demonstrated in several studies with different plant sources (Baig et al., 1970; Arrigoni, 1994; Smirnoff et al., 2004). The reaction is catalyzed by L-galactone-1,4-lactone dehydrogenase (GLDHase), an enzyme found in the inner membrane of mitochondria (Oba et al., 1995; Smirnoff et al., 2001). In sweet pepper, the activity of GLDHase accompanied ripening and was associated with the increase in the AsA levels (Imahori et al., 1998).

Besides strawberries (Agius et al., 2003), to date there are no available studies concerning possible pathways of the biosynthesis of AsA in fruits. The purpose of this investigation was to study the biosynthesis of AsA in different fruits by precursor infiltration, with or without radioactive labeling, in order to corroborate the "Smirnoff-Wheeler" pathway for AsA synthesis in fruits. In addition, we also included broccoli in our study. To our knowledge there is not such information for edible flowers.

\section{MATERIAL AND METHODS}

Plant material: Green sweet pepper, guavas, papaya and broccoli were obtained from a local market. Strawberries, var. Dover, were obtained from a plantation in Atibaia (São Paulo State, Brazil). The ripening stages were defined according to Paull et al. (1996).

Chemicals: L-Galactose (L-GAL), D-mannose (D-MAN), Dglucose (D-GLU), L-galactono-1,4-lactone (L-GL) and metaphosphoric acid were purchased from Sigma Chemical Co. The L-ascorbic acid used as standard was purchased from Merck. Other reagents used were of analytical grade. D-[U${ }^{14} \mathrm{C}$ ]-Mannose (7.4 MBq.mL ${ }^{-1}$ ) was purchased from Amersham Biosciences and L-[1- $\left.{ }^{14} \mathrm{C}\right]$-galactose (3.7 MBq. $\mathrm{mL}^{-1}$ ) from Amersham Radiolabeled Chemicals.

Precursor infiltration: Labeled precursors were fed to strawberries and broccoli florets by immersing the petiole in a solution containing $0.5 \%$ of each precursor, as described by Baig et al. (1970). The green sweet pepper, papaya and guavas were sliced and immersed in the precursor solutions. The zero-time samples were frozen just before infiltration. Controls were immersed in water. After a $24 \mathrm{~h}$ period at room temperature and under artificial light (fluorescent illumination of $40 \mathrm{~W}$, at a distance of $40 \mathrm{~cm}$ ), samples were frozen in liquid nitrogen and kept in freezer until analysis.

Labeled precursor infiltration: Infiltration of labeled precursors was carried out according to Loewus (1963), with some modifications. For the strawberry samples at the mature green stage, sixteen fruits were separately immersed by the petiole in $1 \mathrm{~mL}$ of distilled and deionized water containing $74 \mathrm{kBq}$ of D-[U- $\left.{ }^{14} \mathrm{C}\right]$-mannose or L-[1- $\left.{ }^{14} \mathrm{C}\right]$-galactose, until it was totally taken up. Then, infiltration continued with pure water (no isotope). Samples were taken every $24 \mathrm{~h}$, using 8 fruits. Broccoli samples were treated the same way, but the radioactivity was $37 \mathrm{kBq}$. For the red-pulp guavas, at the mature green stage, and papaya, at the mature green and ripe stages, circular slices from the pulp were taken, in which 3.7 $\mathrm{kBq}$ of D-[U- $\left.{ }^{14} \mathrm{C}\right]$-mannose, D-[1- $\left.{ }^{14} \mathrm{C}\right]$-glucose-P or L-[1$\left.{ }^{14} \mathrm{C}\right]$-galactose were infiltrated. The conversion rate was determined after a $24 \mathrm{~h}$ period.

Ascorbic and dehydroascorbic acids determination: The AsA and DHA were determined as described by Rizzolo et al. (1984). Samples were ground under liquid nitrogen, and homogenized with a $0.1 \%$ metaphosphoric acid solution, in appropriated proportions. Then, the homogenate was centrifuged $\left(12.000 \mathrm{~g}_{n}, 10 \mathrm{~min}\right)$ and the supernatant filtered through a Millipore membrane (0.45 ìm), and diluted with more metaphosphoric acid for AsA determination and with dithiothreitol for the total AsA analysis. The DHA content was determined by the difference between AsA and total AsA contents. The extracts were analyzed by HPLC, using a $\mu$ Bondapak $\mathrm{C}_{18}$ column, and the mobile phase was 0.2 mol.L ${ }^{-1}$ acetate buffer $\mathrm{pH} 4.5$, at a flow rate of $1.5 \mathrm{~mL} \cdot \mathrm{min}^{-1}$. The compounds eluting from the column were detected at $254 \mathrm{~nm}$. A standard curve was obtained from 10 to 100 mmol.L $\mathrm{L}^{-1}$ AsA.

Labeled AsA analysis: The labeled AsA determination was carried out as described by Keates et al. (2000), with some modifications. The AsA peaks were collected after HPLC separation (injection volume $100 \mu \mathrm{L}$ ). The AsA fractions were mixed with $4 \mathrm{~mL}$ of scintillation fluid (ASC ${ }^{\circledR} \mathrm{NASC} 104$, Amersham Biosciences) and counted in a liquid scintillation counter (LSC - TriCarb 1900, Canberra Packard).

Statistical Analysis. All experimental data were assumed to follow a normal distribution and were subjected to an analysis of variance using a fully randomized design. The Tukey test was applied $(\mathrm{p} \leq 0.5)$ to compare means for significant differences. 


\section{RESULTS}

The influence of precursor infiltration on AsA and DHA levels: The results obtained from infiltration experiments with green sweet pepper, mature green and ripe papaya, white-pulp and red-pulp guavas, mature green and half red strawberries and broccoli florets are shown in figures 2 to 6 . In figure 2, it may be seen that for the green sweet peppers the pool size of AsA diminished during the $24 \mathrm{~h}$ infiltration period, although this decline was not statistically significant when L-GL was used as precursor This indicates that L-GL was more effective in maintaining the original AsA levels, while L-GAL and DMAN appeared to be totally inefficient, producing AsA levels similar to the control infiltrated with water. Perhaps the LGL to AsA step is more active in the green sweet pepper, since the other precursors were unable to sustain the initial AsA concentration. The decline in total AsA may be due to a higher degradation involving both ascorbate oxidase (AO) and ascorbate peroxidase (APX), possibly activated by the stress of slicing and the infiltration technique used for the experiment. Evidently, over the infiltration period, the biosynthetic activity was not capable of counter-balancing the catabolic activity, except perhaps for L-GL as precursor.

For papaya, it is interesting to observe that there was substantial synthesis of AsA during ripening, as shown by the 4-fold higher AsA level in the ripe fruit compared with the mature green one (cf. zero-time data of figures $3 \mathrm{~A}$ and 3B). There was a significant increase in total AsA levels only with the L-GL infiltrated sample, both for the mature green and the ripe fruits. Despite the higher level of AsA in the ripe fruits, there was no significant difference in the biosynthetic capacity of mature green and ripe fruits, that were about 12.5

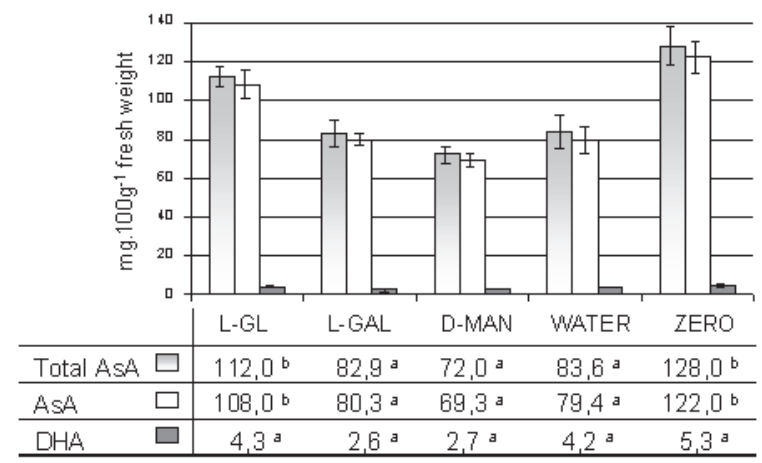

Figure 2. Total ascorbic acid, ascorbic acid and dehydroascorbic acid contents in green sweet pepper infiltrated with different ascorbic acid precursors. The results are the mean of three repetition; means with different letters within rows are statistically different.
$\%$ and $13.6 \%$, respectively. The infiltration with the other precursors seemed to be less effective, showing no significant AsA increase in relation to the controls.

Figures $4 \mathrm{~A}$ and $4 \mathrm{~B}$ show that there were differences between the white-pulp and the red-pulp guava fruits at the mature green ripening stage, respectively. In the case of whitepulp guava, there was no detectable increase associated with precursor infiltration. On the other hand, in red-pulp guavas there was a significant increase of the total AsA contents when the fruit were infiltrated with either L-GAL or L-GL. Lee and Kader (2000) showed that the AsA content in fruits may vary according to the plant cultivar, this being possibly associated with modifications in composition, tissue structure and other intrinsic factors.

In the case of strawberry at mature green and half red stages increases were again found for the AsA and total AsA levels in fruits infiltrated with L-GAL and L-GL (figures 5A and $5 \mathrm{~B}$ ), but not for D-MAN. The increase caused by the LGL infiltration was higher in the half red fruits than in the mature green ( $78 \%$ and $58 \%$, respectively), yet there was no
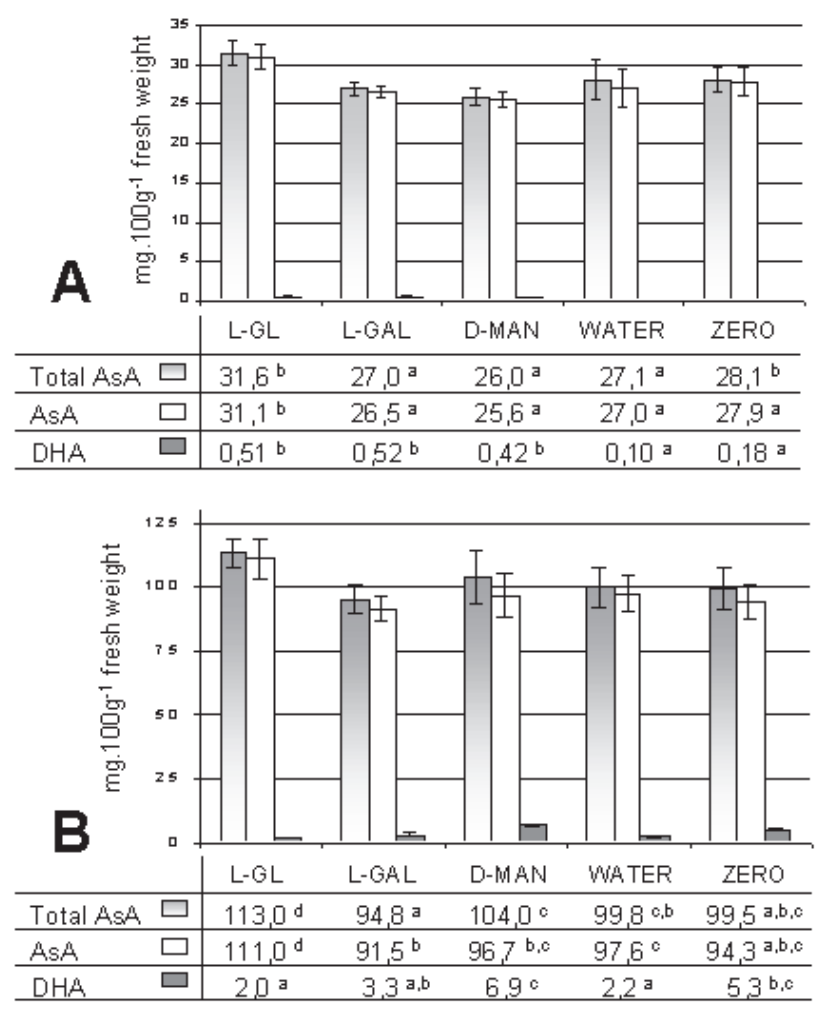

Figure 3. Total ascorbic acid, ascorbic acid and dehydroascorbic acid contents in mature green (A) and ripe papaya fruit (B) infiltrated with different ascorbic acid precursors. The results are the mean of three repetitions, and means with different letters within rows are statistically different. 
difference between the initial AsA content of the mature green and half red fruits. This result might suggest more active degradation in the half red fruits but also that a stronger biosynthetic or regeneration system was present that maintained the AsA content unchanged. Kim and Chung et al. (1998) reported higher APX activity during strawberry ripening.

Since broccoli shows high contents of AsA, it was also included in our studies. There was a great increase in the total AsA in the L-GL and L-GAL infiltrated samples, as compared to the water-infiltrated sample (figure 6). On the other hand, there was no statistical difference in the D-MAN infiltrated sample compared to the water-infiltrated sample. The initial AsA content was higher than in some of the fruits studied, and the increase in rate of synthesis was around $86 \%$.

Conversion of labeled precursor into AsA: The results of the conversion of labeled precursors into AsA are shown in table 1. In all cases, it may be seen that L-GAL infiltration resulted in highly labeled AsA. For ripe papavas, there was a smaller
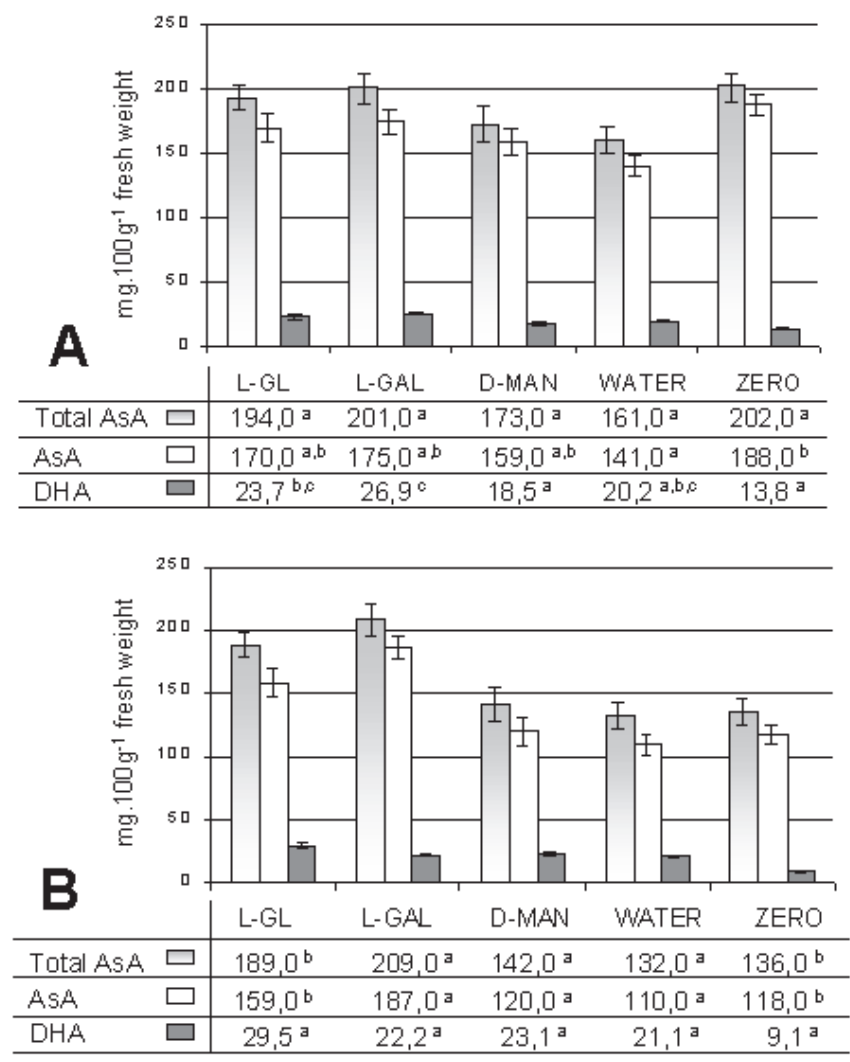

Figure 4. Total ascorbic acid, ascorbic acid and dehydroascorbic acid contents in white-pulp (A) and redpulp (B) guava fruit infiltrated with different ascorbic acid precursors. The results are the mean of three repetitions, and means with different letters within rows are statistically different. increase, which may indicate a lower rate of AsA biosynthesis or higher degradation in this sample. In broccoli, on the other hand, the highest rate of conversion was found, suggesting an efficient formation of AsA from L-GAL. Papaya at the mature green ripening stage also showed a high conversion rate while ripe fruits showed less than half of this rate.

The conversion of labeled D-MAN into AsA was very similar for broccoli and strawberry, while for the red-pulp guava it was the lowest. For the papaya and red guava fruits at the mature green ripening stage, the conversion rate of $\mathrm{D}$ glucose-1P and D-MAN were very similar. Other authors (Keates et al., 2000; Kostman et al., 2001) also found higher conversion of L-[1-14 C]-GAL and lower conversion of D$\left[\mathrm{U}-{ }^{14} \mathrm{C}\right]-\mathrm{MAN}$. The experiments also showed that AsA biosynthesis took place from glucose-1-P as precursor in papaya and red-pulp guava, confirming the 'SmirnoffWheeler' scheme in these fruits. The increase in AsA contents originated by D-MAN and D-GLU-1-P were lower, possibly because these precursors are at the initial steps of the pathway.
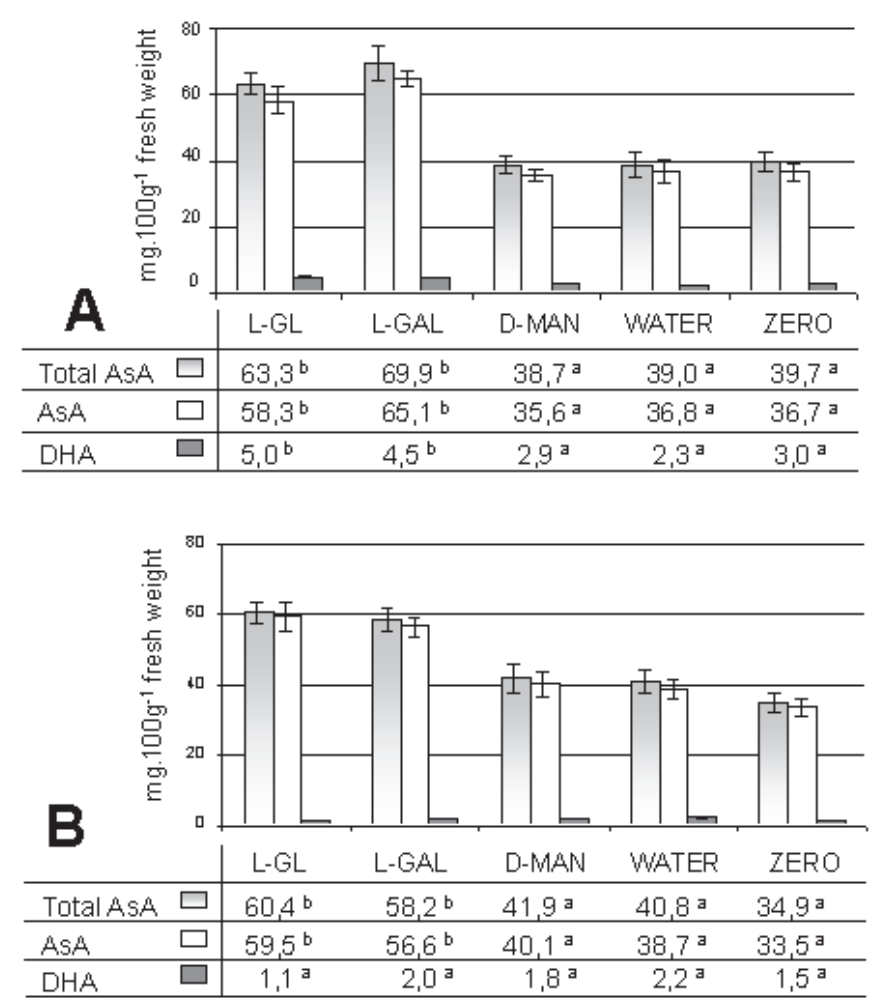

Figure 5. Total ascorbic acid, ascorbic acid and dehydroascorbic acid contents in mature green (A) and half red (B) strawberry fruit infiltrated with different ascorbic acid precursors. The results are the mean of three repetitions, and means with different letters within rows are statistically different. 


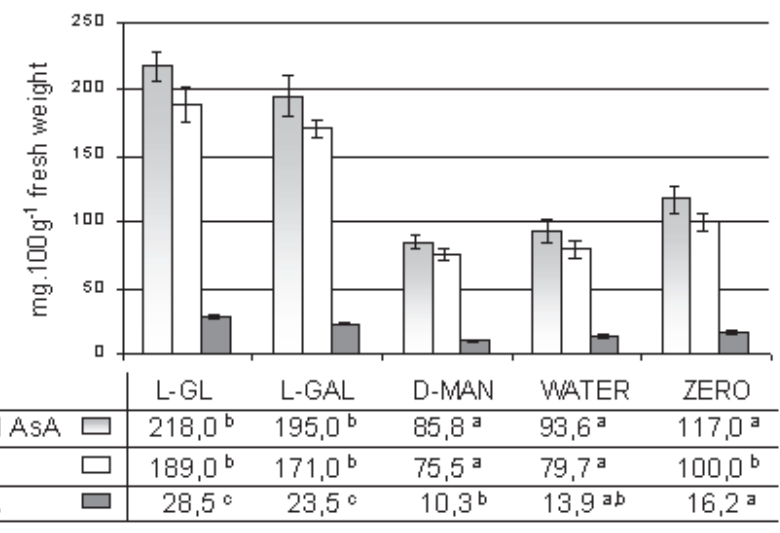

Figure 6. Total ascorbic acid, ascorbic acid and dehydroascorbic acid contents in broccoli florets infiltrated with different ascorbic acid precursors. The results are the mean of three repetitions; means with different letters within rows are statistically different.

\section{DISCUSSION}

Despite the importance of ascorbic acid, only recently has its biosynthetic pathway been elucidated. The pathway proposed by Wheeler et al. (1998) appears to be the main one for the synthesis of AsA in plants. This pathway was shown to be present in different plant sources but, until now, not in fruits. The pathways of biosynthesis and degradation of AsA have been studied with the help of tissue infiltration, sometimes with the use of radioactive labeling. Experiments involving the infiltration of D-[6- $\left.{ }^{14} \mathrm{C}\right]$-glucose and D-[6- $\left.{ }^{14} \mathrm{C}\right]-$ glucosone in bean seedlings and D-[1-14C]-glucose in watercress, parsley and geranium leaves confirmed the conversion of these precursors into AsA (Loewus and Jang, 1957; Williams and Loewus, 1978; Helsper et al., 1982; Loewus et al., 1987).

In our study, the infiltration of L-GL led to an increase of the AsA content in fruits and in broccoli florets, suggesting that the L-galactono-1,4-lactone dehydrogenase activity is responding efficiently to increases in its substrate. The exception was the white-pulp guava, where no effect was obtained for any precursor tested. The infiltration with LGAL also increased the AsA levels in broccoli, red-guava and strawberry (at mature green and half red stages). Although papaya (both mature green and ripe fruits) did not accumulate AsA from L-GAL infiltration, AsA did become labeled after radioactive $\mathrm{L}-\mathrm{GAL}$ infiltration. This fact indicates that $\mathrm{L}-\mathrm{GAL}$ is an efficient precursor, but in papaya, there may be also a higher degradation of AsA which would explain the 5-fold increase in DHA levels observed. Similar results were found for D-MAN infiltration. None of the samples accumulated AsA from D-MAN infiltration, but all samples tested using labeled D-MAN infiltration formed labeled AsA, suggesting a tighter control of the pathway at the conversion of Dmannose to AsA, together with a continuos turnover of AsA. In papaya at the mature green stage, we observed an increase in DHA levels, suggesting that D-MAN infiltration led to the biosynthesis of AsA followed by degradation. Axenic cell culture of Pistia stratiotes L. showed high conversion of LGAL into AsA, the labeled carbon being also incorporated in oxalic acid. The conversion of AsA into AOx and other organic acids has already been shown for different plant sources (Keates et al., 2000; Kostman et al., 2001; DeBolt et al., 2004). The closer the precursor is to the final step of AsA biosynthesis, the higher the conversion rate into AsA. Furthermore, it is possible that the need for mannose phosphorylation is a limiting factor, since it has a high energy requirement and then mannose may be diverted to other pathways.

During fruit ripening, many reactions are still occurring, such as color transformation, sugar synthesis and cell wall degradation. All these phenomena may cause tissue stresses which would require antioxidant action, especially by ascorbate, preventing cell damage. It is conceivable that, due to these stresses, AsA levels would invariably decrease during fruit ripening. However, it would appear that, in some fruit,

Table 1. Percent conversion of D-[U- $\left.{ }^{14} \mathrm{C}\right]$-mannose, L- $\left[1-{ }^{14} \mathrm{C}\right]$-galactose e D-[1- $\left.{ }^{14} \mathrm{C}\right]$-glucose-1-P for different samples, after $24 \mathrm{~h}$ of infiltration ${ }^{\mathrm{a}}$.

\begin{tabular}{lccc}
\hline & D-[U- $\left.{ }^{14} \mathrm{C}\right]$-mannose & L-[1-14C]-galactose & D-[1-14C]-glucose-1-P \\
\hline Papaya (mature green stage) & $9,0 \pm 1,9 \mathrm{a}$ & $58,0 \pm 0,6 \mathrm{~b}$ & $7,1 \pm 0,6 \mathrm{a}$ \\
Papaya (ripe-stage) & - & $25,4 \pm 4,6$ & - \\
Guava (red-pulp, mature green stage) & $3,0 \pm 0,8 \mathrm{a}$ & $39,3 \pm 2,8 \mathrm{~b}$ & $3,7 \pm 0,3 \mathrm{a}$ \\
Strawberry (mature green stage) & $11,2 \pm 2,3 \mathrm{a}$ & $40,9 \pm 5,4 \mathrm{~b}$ & - \\
Broccoli & $11,0 \pm 1,6 \mathrm{a}$ & $67,5 \pm 10,5 \mathrm{~b}$ & - \\
\hline
\end{tabular}

${ }^{a}$ Results are the mean \pm standard deviation $(n=3)$; means followed by different letters within rows are statistically different. 
AsA levels increase greatly while in others, these levels remain unchanged or decrease. Papaya presented a great increase (about 4-fold) in AsA levels from the mature green to the ripe stage of ripening. These results are in agreement with those presented by Wills and Widjanarko (1995), who also found a 4-fold increase in AsA levels during papaya ripening. On the other hand, strawberry did not show significant changes from the mature green to the intermediate stages, but Cordenunsi et al. (2002) showed an increase of about 20 $\%$ from the intermediate to the fully ripe stage in strawberry cv. Dover. The mechanisms that regulate ascorbate content in fruits are still under investigation and possibly the balance between synthesis and degradation processes, which are genetically regulated, also plays an important role.

Finally, the increase or decrease of the AsA and DHA levels from precursors also reflect both enzymatic and nonenzymatic factors. The balance between these factors assures the final content and underlies the variation of AsA levels during ripening or storage processes of different plants.

Acknowledgments: Authors would like to thank FAPESP and CAPES for financial support.

\section{REFERENCES}

Agius F, González-Lamothe R, Caballero JI, Muñoz-Blanco J, Botella Ma, Valpuesta V (2003) Engineering increased vitamin $\mathrm{C}$ levels in plants by overexpression of a $\mathrm{D}$ galacturonic acid reductase. Nature Biotechnol. 21:177-181.

Arrigoni O (1994) Ascorbate system in plant development. J. Bioenerg. Biomemb. 26: 407-419.

Baig MM, Kelly S, Loewus F (1970) L-ascorbic acid biosynthesis in higher plants from L-gulono-1,4-lactone and L-galactono-1,4-lactone. Plant Physiol. 46:277-280.

Conklin PL, Norris SR, Wheeler GL, Williams EH, Smirnoff N, Last R (1999) Genetic evidences for the role of GDPmannose in plant ascorbic acid (vitamin C) biosynthesis. Proc. Nat. Acad. Sci. USA 96:4198-4203.

Cordenunsi BR, Nascimento JRO, Genovese MI, Lajolo FM (2002) Influence of cultivar on quality parameters and chemical composition of strawberry fruits grown in Brazil. J. Agric. Food Chem. 50:2581-2586.

Davey MW, Gilot C, Persiau G, Ostergaard J, Han Y, Bauw GC, Van-Montagu MC (1999) Ascorbate biosynthesis in Arabidopsis cell suspension culture. Plant Physiol. 121:535-543.

DeBolt S, Hardie J, Tyerman S, Ford CM (2004) Composition and synthesis of raphide crystals and druse crystals in berries of Vitis vinifera L. cv. Cabernet Sauvignon: ascorbic acid as precursor for both oxalic and tartaric acids as revealed by radiolabelling studies. Aust. J. Grape Wine Res. 10:134-142.

Gatzek, S, Wheeler, GL, Smirnoff, N (2002) Antisense suppression of L-galactose dehydrogenase in Arabidopsis thaliana provides evidence for its role in ascorbate synthesis and reveals light modulated L-galactose synthesis. Plant J. 30:541-553.

Helsper JP, Kagan L, Hilby CL, Maynard TM, Loewus F (1982) L-ascorbic acid biosynthesis in Ochromonas danica. Plant Physiol. 69:465-468.

Imahori Y, Zhou YF, Ueda Y, Chachin K (1998) Ascorbate metabolism during maturation of sweet pepper (Capsicum annuum L.) fruit. J. Jap. Soc. Hort. Sci. 67:798-804.

Isherwood FA, Mapson LW (1962) Ascorbic acid metabolism in plants. II. Metabolism. Ann. Rev. Plant Physiol. 13:329350 .

Keates SE, Tarlyn N, Loewus FA, Franceschi VR (2000) Lascorbic acid and L-galactose are sources for oxalic acid and calcium oxalate in Pistia stratiotes. Phytochemistry 53:433-440.

Kim, IJ, Chung WI (1998) Molecular characterization of a cytosolic ascorbate peroxidase in strawberry fruit. Plant Sci. 133:699-77.

Kostman T, Tarlyn N, Loewus FAA, Franceschi VR (2001) Biosynthesis of L-ascorbic acid and conversion of carbons 1 and 2 of L-ascorbic acid to oxalic acid occurs within individual calcium oxalate crystal idioblasts. Plant Physiol. 125:634-640.

Lee SK, Kader AA. (2000) Preharvest and postharvest factors influencing vitamin $\mathrm{C}$ content of horticultural crops. Post Harv. Biol. Technol. 20:207-220.

Loewus F, Kelly S (1961) The metabolism of D-galacturonic acid and its methyl ester in the detached ripening strawberry. Arch. Biochem. Biophys. 95:483-493.

Loewus FA (1963) Tracer studies of ascorbic acid formation in plants. Phytochemistry 2:109-128.

Loewus FA, Grun M, Loewus MW (1987) Biosynthesis and metabolism of L-ascorbic acid in plants. Crit. Rev. Plant. Sci. 5:101-119.

Loewus FA, Jang R (1957) Further studies on the formation of L-ascorbic acid in plants. Biochem. Biophys. Acta 23:205-206.

Loewus FA, Jang R, Seegmiller CG (1956) The conversion of ${ }^{14} \mathrm{C}$-labeled sugars to $\mathrm{L}$-ascorbic acid in ripening strawberries. J. Biol. Chem. 222:649-664.

Loewus FA, Wagner G, Yang JC (1975) Biosynthesis and metabolism of ascorbic acid in plants. Ann. New York Acad. Sci. 258:7-23.

Loewus MW, Bedgar DL, Saito K, Loewus FA (1990) Conversion of L-sorbosone to L-ascorbic acid by a NADPdependent dehydrogenase in bean and spinach leaf. Plant Physiol. 94: 1492-1495.

Oba K, Ishikawa S, Nishikawa M, Mizuno H, Yamamoto T (1995) Purification and properties of L-galactono-gammalactona dehydrogenase, a key enzyme for ascorbic acid biosynthesis, from sweet potato roots. J. Biochem. 117:120-124.

Paull RE (1996) Pineapple and Papaya. In: Biochemistry of fruit ripening. In: Seymour GB, Taylor JE, Tucker GA, (eds), Biochemistry of Fruit Ripening, pp.302-315. Chapman \& Hall, London. 
Rizzolo A, Forni E, Polesello A (1984) HPLC assay of ascorbic acid in fresh and processed fruit and vegetables. Food Chem. 14:189-199.

Saito K (1996) Formation of L-ascorbic acid and oxalic acid from D-glucosone in Lemna minor. Phytochemistry 41:145-149.

Saito K, Loewus FA (1989) Formation of tartaric acid in vitaceous plants: relative contributions of L-ascorbic acidinclusive and acid noninclusive pathways. Plant Cell Physiol. 30: 905-910.

Saito K, Nick JA, Loewus FA (1990) D-glucosone and Lsorbosone, putative intermediates of L-ascorbic acid biosynthesis in detached bean and spinach leaves. Plant Physiol. 94: 1496-1500.

Smirnoff N (1996) The function and metabolism of ascorbic acid in plants. Ann. Bot. 78:661-669.

Smirnoff N, Conklin PL, Loewus FA (2001) Biosynthesis of ascorbic acid in plants: a renaissence. Annu. Rev. Plant Physiol. Plant Mol. Biol. 52:437-467.
Smirnoff N, Running JA, Gatzek S (2004) Ascorbate biosynthesis: a diversity of pathways. In: Asard H, May JM, Smirnoff N (eds.), Vitamin C: its Functions and Biochemistry in Animals and Plants, pp.7-29. BIOS Scientific Publishers, New York.

Smirnoff N, Wheeler GL (2000) Ascorbic acid in plants: biosynthesis and function. Crit. Rev. Plant Sci. 19:267-290.

Wagner G, Loewus FA (1974) L-ascorbic acid metabolism in vitaceae: conversion to $(+)$-tartaric acid and hexoses. Plant Physiol. 54(5):784-787.

Wheeler GL, Jones MA, Smirnoff N (1998) The biosynthetic pathway of vitamin $\mathrm{C}$ in higher plants. Nature 393:365-369.

Williams M, Loewus FA (1978) Biosynthesis of (+)-tartaric acid from L- $\left[4-{ }^{-14} \mathrm{C}\right]$-ascorbic acid in grape and geranium. Plant Physiol. 61:672-674.

Wills RBH, Widjanarko SB (1995) Changes in physiology, composition and sensory characteristics of Australian papaya during ripening. Aust. J. Exp. Agric. 35(8):1173-1176. 